\title{
Interreligious Dialogue, Comparative Theology \\ and the Alterity of Hindu Thought
}

\begin{abstract}
A key question at the heart of contemporary debates over interreligious dialogue is whether the Christian partner in such conversations should view her interlocutors through the lens of Christian descriptions or whether any such imaging amounts to a form of Christian imperialism. We look at the responses to this question from certain contemporary forms of 'particularism' which regard religious universes as densely knit, and sometimes incommensurable, systems of meanings, so that they usually deny the significance, or even the possibility, of modes of Bible preaching such as apologetics. While these concerns over the alterity of other religious traditions are often viewed as specifically postmodern, two Scotsmen in British India, J.N. Farquhar (1861-1929) and A.G. Hogg (1875-1954), struggled exactly a hundred years ago with a version of this question vis-à-vis the religious universe of Vedāntic Hinduism and responded to it in a manner that has striking resemblances to 'particularism'. We shall argue that Hogg can be seen as an early practitioner of a form of 'comparative theology' which emerges in his case, on the one hand, through a textual engagement with specific problems thrown up in interreligious spaces but, on the other hand, also seeks to present a reasoned defence of Christian doctrinal statements. We shall note a crucial difference between his comparative theological encounters and contemporary practitioners of the same - while the latter are usually wary of speaking of any 'common ground' in interreligious encounters, Hogg regarded the presuppositions of the Christian faith as the basis of such encounters. The writings of both groups of theologians are structured by certain 'dilemmas of difference' that we explore.
\end{abstract}


KEYWORDS: interreligious dialogue, comparative theology, particularism, A.G. Hogg, J.N. Farquhar, R. Otto, G. Lindbeck, F. Clooney

A recent move in debates over religious diversity in philosophy of religion, missiology, theology of religions, and elsewhere is to reject attempts to subsume the religious other within a theoretical account of Religion, and instead to affirm the radical alterity of each of the religious strands of humanity. Christian theologians who adopt this standpoint often argue that Religion, characterised as an outdated product of the European Enlightenment, is a form of ethnocentric universalism which seeks to assimilate the religious traditions of the world to the normative homogenizing frameworks of its European origins. Instead, they assert that each religion is a distinctive finely-spun web of texts, traditions and teachers, and its internal coherence, structure and integrity must not be violated by encompassing it as one more instance of Religion. A key question, however, that they have to struggle with is precisely over the conceptualisation of the 'alterity' that they seek to emphasise: is it so radical that the other is consigned to a zone of inaccessible otherness or is it possible somehow to set up overlapping, criss-crossing identities through interreligious dialogue?

In this essay, keeping this question in mind, we have three main objectives: first, to lay out the contours of the debates over 'alterity' among some contemporary Christian theologians; second, to note certain precursors of these debates among Christian missionary thinkers in late colonial India as they engaged with the structures of Hindu thought; and third, to highlight the significant conceptual shifts between the earlier debates and the contemporary ones. While the debates over alterity are sometimes signalled as a defining characteristic of postmodernity, we shall indicate that they had reached a sophisticated pitch in British 
Christian missionary responses in the 1920 s to certain aspects of Hindu thought. That is, the question 'precisely how other is the other?' is not a contemporary invention but a theologicalphilosophical puzzle that several Christian theologians and missionaries grappled with in British India. Further, and crucially, while they were aware avant la lettre of the postmodern themes of incommensurability, heterogeneity, locality, and the like, they were also able to affirm, in realist fashion, the common unity and destiny of all humanity under Christ. Therefore, a key question that our essay will raise is whether interreligious dialogue is thwarted or enabled by the realist 'presupposition' of the Christian world-view that all human beings are in fact encompassed by the Triune God.

\section{THE ‘PRESUPPOSITIONS’ OF INTERRELIGIOUS DIALOGUE}

A vital theme in recent debates over interreligious dialogue is whether it is possible to hold together in a creative tension the demands of identity and authenticity to one's religious tradition with openness to other traditions. From a broad historical perspective, we can identify at least three dialectical 'turns' in Christianity's engagement with the religious other, and, more specifically, Hindu thought. Till around 1900, Christian theologians and missionaries usually viewed the cluster of beliefs and practices that gradually began to be subsumed under the label 'Hinduism' as the demoniac other to Christian truth, a degraded perversion that needed to be corrected through Christian light. ${ }^{1}$ From this standpoint, most clearly exemplified in Alexander Duff's reference in 1839 to Hinduism as 'a stupendous

system of error', ${ }^{2}$ the emphasis falls clearly on the radical otherness of Hindu structures of belief and practice: the latter is defined in terms of an absence, defect or lack relative to Christian presence. From around the 'turn' of the century, however, British Protestant figures such as T.E. Slater and, more famously, J.N. Farquhar began to place the religions of the 
world on a continuum, at the apex of which stood Christianity. For instance, Slater argued that while non-Christian religions such as Hinduism, encompassed within divine providence, contain 'pre-sentiments' of Christian truth, they are, however, are incomplete unless they are fulfilled in Christianity which stands at the summit of the evolutionary scale of religions. ${ }^{3}$ Slater's argument is echoed in Farquhar's claim that the multiplicity of Hindu beliefs and practices reveals that there is at its heart a complex of needs, such as the one for a personal saviour, which can be fulfilled not within Hinduism itself but by the reality of Christ who alone can truly satisfy them. ${ }^{4}$ The basic presupposition of these strands of 'liberal Protestantism', that all human beings share certain religious aspirations which are perfectly fulfilled only in Christ, therefore, views the 'alterity' of Hindu thought in terms not of utter error but of perfectible intimation of Christian truth. John Hick's 'hypothesis' that the major religious traditions of the world are orientated towards a Real an sich to which none of the concrete images used in these traditions apply can be seen as a late development of this mode of engaging with the religious other. By dropping the notion of the 'perfectibility' of one tradition in terms of another, Hick argues that human beings within their distinctive traditions are engaged in contexts of moral transformation from self-centredness to rootedness in the Real. ${ }^{5}$ The third 'turn', however, which begins to emerge from the closing decades of the last century, rejects the fundamental presupposition that there is an 'underlying unity' across the religious streams of humanity, and instead emphasises the radical distinctiveness of each of these religious traditions. ${ }^{6}$

The group of Christian theologians whom we will discuss in this essay broadly agree that the maintenance of this dynamic equilibrium requires the rejection of a 'meta-theory' which would co-opt the distinctive particulars of the religious traditions within an over-arching 
scheme of Religion, Reality, Salvation and so on, which are said to disfigure these specificities. ${ }^{7}$ Given their concern to highlight the distinctive particularities of the religious traditions, their tradition-shaped formations and their textually-grounded architectures, the label 'particularist' has sometimes been applied to these theologians who argue that a 'preemptive' a priori theology of religions is often disinterested in the specifics of the aims and forms of life pursued by non-Christians. ${ }^{8}$ While, as we will note shortly, the particularists differ among themselves regarding the question of whether the particularities of the other religions can be 'comprehended' through conversational discourse, they strike the note that the assumption that the religious traditions share a 'common ground', staked out by presuppositions regarding the religious other, limits the strangeness, the novelty, and the uniqueness of what is being heard. ${ }^{9}$ By removing such presumptions from the conversation, the otherness of the dialogical partner should instead be acknowledged from the start, as also the possibility of divergences across the doctrinal statements of religious communities. ${ }^{10}$

The central question which lies at the heart of these debates over the role of 'theory' in interreligious conversations can be framed as: how much by way of 'presupposition' can a Christian theologian bring to the interreligious dialogue? Theologians in both the first and the second 'turns' operated with the 'presupposition' that they inhabited a world structured by Christian truth within which they tried to 'locate' religious diversity in somewhat divergent ways. In contrast, theologians who advocate the third 'turn', given their hesitation to speak in terms of any common ground across religious traditions, seem to suggest a 'presuppositionless' point of entry into debates over religious diversity. We will note that this question operates as a parting of the ways between those Christian theologians who seem to respond 'none at all' and other Christian theologians who affirm the centrality of a Christ-shaped 
reality in the process of the interreligious dialogue. If we describe the former standpoint as 'strong particularism' (SP) and the latter as 'weak particularism' (WP), their mutual divergence can be phrased in the following ideal-typical manner.

SP: I approach the partner in interreligious dialogue without viewing her through any descriptions whatsoever drawn from my Christian traditions. For instance, I do not regard her as a 'child of the Triune God', and a fortiori as an individual encompassed by the saving reality of Christ. Every religious scheme is a densely textured universe, a semiotic system which shapes communitarian identity, and no such 'translations' can be possible across their incommensurable horizons.

WP: I approach the partner in interreligious dialogue without viewing her through the structures of institutional, historical and sociological Christianity, while acknowledging that precisely what these structures are remains an intensely contested matter in Christian theological circles. However, I regard her as a 'child of the Triune God', even while I admit that she herself would not accept this description. Indeed, while even I highlight the difficulty of 'translations' across religious boundaries, I nevertheless believe that to regard an individual as in fact not 'a child of the Triune God' would be to abandon the very centre of Christian faith.

In other words, the debate is over whether the doctrinal teachings of Christianity should retain a normative status in 'comprehending' religious diversity: SP would reject every vestige of this normativity as an intrusion of presumption, while WP sees it as an unavoidable aspect of religious commitment and identity. ${ }^{11} \mathrm{We}$ need to highlight the ideal-typical nature 
of this schematic distinction, for as we shall note shortly, most of the contemporary particularists who have contributed to debates over interreligious dialogue straddle in fact the boundary between SP and WP.

\section{STRONG PARTICULARISM: INCOMMENSURABILITY AND MULTIPLE} 'SALVATIONS'

Let us begin with some contemporary Christian theologians who would seem, at least on a first reading, to affirm SP. According to the post-liberal theology of George Lindbeck, we should not strictly speak of 'damnation' outside the Church any more than 'salvation' in such contexts, for religions such as Christianity should be viewed along the lines of distinct linguistic structures into whose comprehensive frameworks individuals should be woven before they can begin to learn their respective grammars. ${ }^{12}$ Emphasising the note of incommensurability, Lindbeck argues that 'when affirmations or ideas from categoreally different religious or philosophical frameworks are introduced into a given religious outlook, these are either simply babbling or else, like mathematical formulas employed in a poetic texts, they have vastly different functions and meanings than they had in their original settings'. ${ }^{13}$ Therefore, religions should be seen in terms not of a set of propositions scrutinised by public reason or of inner experiences shared universally but of highly specific and rich categories through which reality is apprehended, experience is narrated and life is ordered in each of the world religions. Lindbeck rejects two models of understanding religion which are based on the extra-textualist assumption that all human beings have access to certain truths or experiences which are represented in religious texts: cognitivepropositionalism which views religion in terms of doctrines which embody truth-claims about reality, and experiential-expressivism which regards religious doctrines as the expressions of 
the life of spirituality. Instead, his cultural-linguistic model, which views religion as a regulative structure for reflection and conduct, is intra-textual in that the meaning of a text is to be located within the specific discourse which constitutes it. That is, religious concepts get their meaning not from entities that they supposedly refer to or from experiences that they may evoke, but from how they operate within a semiotic system of symbols and actions. Therefore, instead of viewing the Cross as a representation of a 'universal' experience of suffering, Christians will rather view suffering as cruciform - and more generally, the entire world is to be viewed through the spectacles of scriptural revelation.

Further, according to Lindbeck, theology should be regarded as a second-order activity, along the lines of 'grammar': just as the grammar of a language is neither true nor false because it asserts nothing about extra-linguistic entities but stipulates rules for organizing speech and writing into meaningful bits, so too theological statements are not truth-claims about a preexistent reality but second-order regulative principles or grammatical rules of the Christian conceptual system. Just as one does not speak 'language' in general, only specific languages, according to Lindbeck religions should not be regarded as manifestations of a common essence but as highly particular singularities with distinctive, possibly even incommensurable, notions of truth, experience and so on. Thus Lindbeck argues: 'Not only do they [the religions] no longer share a common theme such as salvation, but the shared universe of discourse forged to discuss that theme disintegrates ... Those for whom conversation is the key to solving interreligious problems are likely to be disappointed' ${ }^{14}$ However, while Lindbeck clearly emphasises SP in these remarks, he also argues that eschatologically the 'categoreal adequacy' of Christianity will be manifested, when after death both believers and non-believers will be confronted by Christ for an explicit offer of redemption. ${ }^{15}$ In other words, while certain statements of Lindbeck would seem to place him 
in SP, his overall eschatological standpoint regarding how to approach the religious other is WP: since the fullness of Christian truth will be revealed on the eschatological horizon, the religious other is in fact encompassed by Christ at all times, even if the religious other must not be approached with Christian descriptions pre-eschatologically.

More schematically, the reason why particularists qua particularists cannot consistently affirm SP is that SP would undercut their own claims to have rejected any aspirations to neutral vantage-points above the fray of the world's religious traditions. Christian theologians who affirm SP and who therefore cannot utilise any home-grown descriptions whatsoever would have to apprehend their dialogical partners as 'bare individuals', which is precisely the Enlightenment notion of abstract individuality that they otherwise reject. More concretely, a theologian who subscribes to SP and who encounters, say, a Vaishnavite Hindu in interreligious dialogue would have to engage with the following dilemma. On the one hand, because she cannot view her interlocutor as a 'child of the Triune God', she would have to describe her as 'a devotee of Vishnu'. On the other hand, if she regards this appellation as an accurate description of the way things are, she would have to deal with the complex question of whether Christ and Vishnu are both ontological ultimates on the eschatological horizon, which she would answer in the negative insofar as she remains within the bounds of Christian orthodoxy. Consequently, she would have to reject the description 'a devotee of Vishnu' as a false one, and instead employ some such locution as 'a human being' to refer to her dialogical partner, which would precisely be an instance of the abstractions she would otherwise seek to reject. In other words, in relegating the other to a zone of radical, static and final inaccessibility, albeit out of respect for the integrity of the other, SP seems unwittingly to imply that the other is a contamination that threatens to invade the purity of the self, the 
self which according to Christian orthodoxy is not a secure possession but a relational entity. Partly in response to such dilemmas, post-liberal theologians such as William Werpehowski have attempted to develop conversational spaces across Christianity and secular world-views, in this case, Marxism. Given that there are some alliances between Christians and Marxists in their struggles for social justice, the Christian theologian can argue that the Christian view of human needs, dependence and freedom is a better account of the realities that both Christians and Marxists accept in their different ways. Such ad hoc apologetics does not assume that Christian and Marxist views about religion can be translated without remainder into one another, or that there exist theory-neutral norms of adjudicating between these two perspectives on reality, and is yet able to offer various apologetic strategies for this exchange to take place between believer and unbeliever. ${ }^{16}$ Consequently, though post-liberal theologians are often accused by their critics of retreating from the public sphere into the 'fideism' of SP, they need not be taken to deny the possibility of limited translation or the existence of any rational spaces between Christians and others. Rather than developing a single knock-down justificatory argument for Christian theism, ad hoc apologetics can be regarded as the attempt to offer provisional, contextual demonstrations of the assimilative power of Christian beliefs to offer intelligible and coherent explanations of the different situations Christians encounter in the world. ${ }^{17}$

\section{WEAK PARTICULARISM: INTRA- AND INTER-RELIGIOUS DIALOGUE}

Comparative theology is a form of particularism which seeks such provisional, contextspecific results in the course of conversations with the religious other who is viewed not as steeped in inaccessible alterity but as a dialogic partner who can generate novel understandings of reality and with whom one can engage in a learning process. ${ }^{18}$ In the words 
of perhaps its best known exponent, Francis Clooney, comparative theology is a 'truly constructive theology, distinguished by its sources and ways of proceeding, by its foundation in more than one tradition (although the comparativist always remains rooted in one tradition), and by reflection which builds on that foundation, rather than simply on themes or by methods already articulated prior to comparative practice. Comparative theology is a theology deeply changed by its attention to the details of multiple religious and theological traditions, a theology that occurs only after comparison'. ${ }^{19}$ Hence, comparative theology is practised not by those who seek 'grand theory' along the lines of a 'theology of religions' but by those who are 'willing to engage in detailed study, tentatively and over time'. ${ }^{20}$ In other words, the conversational process does not reduce the other to a replica of the same so that their concrete 'otherness' is not genuinely heard or appreciated; rather, only by allowing oneself to be addressed, interrupted and surprised by new insights does one move towards partial, tentative results. However, the very fact that comparative theologians speak of such moments of mutual interrogations, interjections and interlocutions shows that, even while they emphasize that the religious other is not a pre-fabricated entity but an elusive presence, structured by alternate modes of thought and practice, such alterity is not viewed through the lens of incommensurability.

Comparative theology, then, is structured by a double moment of anti-theoretical negation and pro-dialogical affirmation. On the one hand, it rejects the pretensions of neutrality and universalist encompassment that it sees in attempts to study Religion in an objective, scientific manner and explicitly recognises the normative commitments that the comparative theologian brings to the conversations between localised texts, teachings and practices - to this extent it can be located in SP. Clooney firmly places 'comparative theology' within the fides quaerens intellectum tradition and argues that it aims at 'knowing a loving God more 
completely and intelligently'. ${ }^{21}$ On the other hand, the inter-religious dialogical engagement with the other traditions is structured by a critical self-consciousness which seeks tentative experimental results by working through topics from other religious traditions - in this aspect it affirms WP. ${ }^{22}$ The creative appropriation of the other takes place as Christian theology is being formulated, and is not a mere appendage to a full formed theology. ${ }^{23}$ Comparative theology, therefore, is work in continual progress, and comparative theologians themselves have sometimes been described as pilgrims, who temporarily inhabit the in-between spaces between traditions, undergo the unhomeliness that such habitation produces, and seek to return to their more familiar locations, creatively transformed by the processes of journeying and arrival. ${ }^{24}$

Clooney's distance from SP is clear particularly in his conviction that Christian theology must be practised in spaces that are at once comparative, interreligious and confessional. In his book Hindu God, Christian God, he seeks to reflect on theological topics such as the existence of God, divine embodiment and revelation from Hindu and Christian perspectives. For instance, Clooney shows that Hindu figures such as Jayanta Bhatta developed a 'rational theology' in defence of God's existence while others such as Ramanuja argued that scripture is the only source of knowledge in matters relating to God, and these debates are structurally similar to ones in Christian circles over the possibility of natural theology. Thus, pointing out that Karl Barth's doctrine of revelation has Hindu analogues, he claims that Barth 'thinks like a Hindu' and that certain Hindu theologians are in fact 'Barthians'. ${ }^{25}$ Indeed, his goal is to 'unsettle the religious and theological boundaries that have neatly divided theologians according to their religions ... [W]hether theologians are Hindu or Christian they are still colleagues and at least intellectually accountable to one another' ${ }^{26}$ Clooney's argument here is not that Hindu debates can be neatly mapped onto Christian ones, or vice versa, but that 
carefully study of texts in languages such as Latin, Sanskrit and Tamil can illuminate certain parallels across theological boundaries between the ways in which Hindus and Christians have grappled with the divine reality. That is, Clooney seeks to hold together, in a creative tension, his point of departure in a Christian theological universe and his ongoing journey through the inter-textual spaces of the complexities and the densities of the Hindu theological universes.

\section{WP AND CHRISTIAN MISSIONARIES IN BRITISH INDIA}

The form of WP called comparative theology, then, seeks to creatively work with elements of similarity and difference across religious traditions, and in this respect it has a significant precursor in the writings of some British Christian missionary thinkers in late colonial India who too struggled with the continuities and the disjunctions between the Christian message and the Hindu worlds. At the same time, we will also note that these thinkers affirmed the universal reach of the Christian gospel much more unequivocally than contemporary forms of $\mathrm{WP}$ - a theme that we will return to shortly.

Two Scotsmen who were engaged with the 'religions of the East', John Nicol Farquhar (1861-1929) and Alfred George Hogg (1875-1954) in colonial India, wrestled with a question that remains alive in contemporary Christian theological discourse on interreligious dialogue - a question that, in fact, marks the divide between SP and WP: is Christian 'salvation' the specific goal only for Christians (as SP asserts) or is the distinctively Christian end of 'salvation' somehow translatable across religious boundaries (as WP affirms)? In other words, they debated the question of the universality of the Christian message and the reality 
of the 'salvation' wrought in Christ, even for those who do not yet have specific knowledge of this saving action. At the heart of this question lies a dilemma that appears in the writings of these two figures: if Christianity is related to the 'religions' simply as their fulfiller, Christianity's own distinctiveness would seem to be obscured, but if the radical break between the two is overemphasized Christianity would arguably be unable to meaningfully address the human condition of those who have not yet heard the gospel.

To use the terms of our earlier discussion, we will note that Farquhar's own position was criticized for not affirming certain elements of SP, while these critics themselves had to grapple with the question of how, given their affirmation of these elements of SP, the gospel could be translated across religious boundaries. J.N. Farquhar argued that a 'religious sensibility', which was a central feature of human existence, had expressed itself in manifold ways in different religions, and all of these had to be granted some legitimacy. However, Christianity stood at the apex of the evolutionary scale and Christianity alone, a spiritual faith with an ethical dimension and based on historical facts, could satisfy those aspirations of human beings which had found imperfect expression in the Hindu religious schools of the Vedānta. ${ }^{27}$ On the basis of Matthew 5.17, 'I am not come to destroy, but to fulfill', Farquhar therefore claimed that Christianity was the crown and the fullness of the truth of the partial revelations of God that were present in the religions of the world, and all these imperfect and rudimentary fragments were to find their fulfillment in Christianity ${ }^{28}$ Farquhar's view did not go unchallenged in his own times, and some of his critics, who emphasised that Christ came into the world not to fulfil the 'pagan' deities but instead of them, believed that Farquhar was, in effect, defending 'idolatry' and 'polytheism'. Farquhar himself was quite clear that the hiatus between Christianity and the other religions could be bridged only when human beings 
consciously turned towards God with utter sincerity and rejected their older beliefs and practices. Consequently, Farquhar's thesis must not be mistaken for the view that all the world religions 'automatically' flow on their own into Christianity even in the absence of the gospel which would make their adherent realize their own imperfections and seek fulfillment in Christ, a concomitant of which is a radical purging of their older elements. Rather, Farquhar's standpoint on religious diversity should be seen as the simultaneous affirmation of his views, on the one hand, that 'the beginnings of the highest are visible in the lowest' and, on the other hand, that though Hinduism possesses many valuable truths, it too 'must die in order to live. It must die into Christianity'. ${ }^{29}$

Nevertheless, some of Farquhar's critics believed that he had not sufficiently emphasized the nature of the disjuncture between the religions and Christianity, on the grounds that the two revolved around different axes, and no gradual progression could be possible from the latter to the former. D. Mackichan, for instance, believed that the gospel does not supplement but supplants the spiritual achievements of Hinduism, and that the 'dark shadow of failure' lies across the religious history of India, for it has failed to arrive at the true knowledge of God. ${ }^{30}$ Again, referring to the phrase 'crown of Hinduism' as 'little more than a debating point', A. Hogg doubted that it was possible to draw lines of continuity that led from the fragmentary truths of Hinduism to their complete fulfillment in Christianity for Christianity not only replaces certain aspects of the former but also fills in much that was never present in it. More importantly, he believed that Hindus would come to Christ only when they consciously feel that Christ fulfils their spiritual hunger, and it is only when this hunger is awakened in them that they can receive Christ. ${ }^{31}$ In effect, Hogg opposed the implication of the fulfilment theme that all human beings are in some sense 'naturally' Christian. A clear example of this 
understanding of Christianity as specifically suited to fulfilling the Hindu's 'need for a Gospel' can be found in J.R. Bacon who argued that Jesus Christ was the genuine historical response to that very need such that ' $[\mathrm{t}] \mathrm{he}$ two may be regarded as halves of the one great whole' ${ }^{32}$ In contrast, Hogg believed that human beings do not, in fact, have such a 'natural' need for Christ, until they become conscious of it through their contact with the gospel, which therefore simultaneously produces it and can satisfy it. In other words, only within the Christian circle of faith that the right kind of seeking becomes possible, for it is by entering into the world of the Bible that the correct aspirations are evoked in human beings, aspirations which can be satisfied only by Christ. ${ }^{33}$ In these remarks, Hogg would almost seem to echo SP's emphases on the alterity of, even incommensurability across, religious traditions.

The view that the criterion of religious truth is not some form of trans-culturally dispersed 'religious experience' but Christ himself, who is the 'criterion' to determine where truth is to be found, also appears in Rudolf Otto in an early comparative study between Christianity and bhakti religiosity. Drawing an analogy from crystallography, Otto writes that just as two crystals which have been precipitated from the same chemical solution have, because of their different axial systems, fundamentally different structures and properties, so too the 'spirit of a religion is decidedly determined by the axis on which it turns, by the centre about which all the other religious ideas are grouped, to which they point, and from which they get their peculiar tone, and the whole obtains its individual structure'. ${ }^{34}$ After claiming that the bhakti religion of India possesses certain characteristics which bear an 'astonishing similarity' to the central Christian themes of 'sin', 'salvation', and 'grace', he argues, almost in the style of SP, that Christianity and the bhakti religion revolve round two entirely different axes because 
the 'spirits' of the two are distinct from each another. Consequently, to move from the world of the Gita to that of the Gospel involves a 'complete displacement of the axis' and not some gradual evolution. ${ }^{35}$

\section{HOGG’S PARTICULARISM AS ‘COMPARATIVE THEOLOGY’?}

Our discussion has shown that Hogg and Otto strikingly anticipate some of the key concerns of comparative theology - religions such as Christianity have a sui generis character, and they should not be viewed as instances of an abstract religious consciousness. Almost echoing SP, Hogg argued that while there were several resonances between elements of Christian doctrine and Hindu conceptions of the deity, there was also an 'irreducible surd of

difference' between the two in that the Hindu does not confess Christ as the only Saviour. ${ }^{36}$ At the same time, however, in the manner of comparative theology's emphasis on WP, he resisted the view that this 'surd of difference' between Christian and non-Christian responses to God were to be read as genuinely incommensurable; rather, he argued that one should speak of degrees of continuity between the responses to God. ${ }^{37}$ Indeed, all the theologians we have encountered so far - ranging from Farquhar on the one hand, and his critics such as Mackichan, Hogg and others - would argue that while there is no 'automatic' rectilinear transition from the religions to Christ, the religions and the Christian gospel are not totally disjointed either, and consequently conversations can take place across their boundaries. Hogg's book The Christian Message to the Hindu is a classic example of such a textuallygrounded interreligious conversation on the field: after encountering Hindu undergraduates who sought a Christian response to the problem of 'unmerited suffering', Hogg, who was the 
Principal of Madras Christian College (1930-38) felt that it was one to "which the Christian Church has formulated no answer'. He writes: 'That controversial challenge sent me to a study of Hindu thought about karma ... Also it made me study afresh the Biblical revelation ... I was not theologically so ignorant as to be unaware of how much the enigma of unmerited suffering had done to shape the development of Old Testament faith, and how relevant to it was the New Testament teaching about the Cross of Christ. But I began to see all this in a new alignment which presented me with issues more clearly cut, and deepened my understanding. ${ }^{38}$ As he responds to the Vedāntic Hindu doctrine of karma and rebirth, Hogg writes that it asserts that there is a 'relative proportionment ${ }^{39}$ between the empirical joys and sorrows of an individual and her moral deserts in this and previous lives, even if this proportionment is not readily visible or manifest to the eye. Hogg goes on to emphasise that there are two strands underlying this conception, one of which is the doctrine of transmigration and the other the view that there is a moral order in the universe so that no individual experiences unjust suffering, and Hogg writes that whatever may be a Christian theologian's final conclusion concerning the former, the latter remains crucial to Christian reflections on the problem of suffering. In any case, Christian theologians have not developed any systematic theory for the question of the 'distribution of suffering' among human beings, and the ultimate reason for this, Hogg argues, is the Christian conviction that in the midst of all worldly travails Christ, who suffered more than anyone, is present to those who are in agony, and that as the loving God He did not want to remain extraneous to their struggles on earth. Our concern here is not to analyse the merits of Hogg's understanding of the Christian doctrine of the atonement, nor to indicate how Hindu thinkers might respond to Hogg's articulation of their position, but to point out how he echoes the comparative theologian who does not presume to start from a position of neutrality or a meta-theory of Religion, but 
struggles creatively with the tension of rootedness in the home tradition of Christianity and vulnerability to the truths in the other religion's doctrinal statements.

Yet, there is also a crucial difference between Hogg's comparative theology and many contemporary practitioners of this modality of interreligious encounter - while the latter often shy away from any apologetic element in interreligious dialogue, Hogg did not, as we noted above, see them as opposed. For instance, while arguing that both similarity and difference are important for the comparative theologian, James L. Fredericks writes that he nevertheless places the emphasis on difference because he seeks to avoid theories that would annul the alterity of other religions. ${ }^{40}$ In contrast, Hogg's comparative theology was more firmly based on an analysis of the competing religious truth-claims across the 'surd of difference' that he identified between Christianity and Hinduism, and his book was an attempt to present what he believed to be the merits of the Christian understanding of Christ's sacrificial death over the Hindu understanding of karma and rebirth as a response to the problem of unmerited suffering. Thus, he argued that while for Christians the fundamental 'question' is the direction they must take to obtain salvation with the 'answer' given to them through God's atoning death in Christ, for Hindus this pair is constituted by their search for release from the cycle of rebirth and the multiple ways of liberation propounded by the schools and sects. Even further, he could write that Hindus would come to Christ only when they consciously feel that Christ fulfils their spiritual hunger, and it is only when this hunger is awakened in them that they can receive Christ. Thus, what Christ fulfils 'is not Hinduism but the need of which India has begun to be conscious, the need of which He [Christ] has made her begin to feel consciousness, by making her feel conscious of which, He has made her no longer quite Hindu'. ${ }^{41}$ 


\section{THE DIGNITY OF DIFFERENCE AND INTERRELIGIOUS DIALOGUE}

The conceptual, cultural and historical shifts that have taken place between the times of Hogg and contemporary comparative theologians such as Fredericks partly help to explain why the latter are relatively uneasy with affirming 'similarity' across religious traditions. In various strands of contemporary socio-cultural life in the west, as well as some sectors of western academia, the emphasis falls squarely on difference - whether in multiculturalism, Wittgensteinian language-games, social anthropological relativism, and so on, the motto seems to be that difference is intrinsically dignified. This motto can be seen at work especially in the post-liberal theology of George Lindbeck and Hans Frei, which veers in the

direction of SP and argues that the 'truth' of Christian discourse should be understood in terms of the communitarian uses to which it is put and not because it corresponds to a reality that is universally accessible. Therefore, a clear distinction is to be made between 'dogmatic theology' and 'apologetics': theology is to be practiced within the horizon of the scriptural world and should not be unduly concerned with establishing its meaningfulness to skeptics and atheists or developing foundations from which its truth can be demonstrated to those outside the Christian form of life. The meaning of the Bible lies in its literary world and not in historical events or contexts that they report, so that the primary concern of Christian theology is the description of the reality of Christ in the scriptural story rather than the translation of this reality into extra-biblical categories. ${ }^{42}$ Without entering into the extensive literature on post-liberal theology, we note that its opposition to the 'translation' projects of inter-religious dialogue would seem to conflict with the universalist faith that the Christian message somehow speaks to an objectively characterized condition of all human beings. 
While the SP of post-liberal theology regards statements about God, Christ, sin and redemption as 'true' only intra-systematically, the 'objects' of these statements are, however, not only 'performed' in a liturgical sense but also pre-exist the confessional setting. Therefore, the Christian community does, after all, make truth-claims about the world, a world that its members share with skeptics, atheists and adherents of other religious traditions, though, of course, they view its creaturely status and hope for its redemption through divine grace in sometimes very different ways. While we may have to participate in specific liturgical contexts to learn the meaning of the statement 'The Triune God is our refuge and strength', its truth or falsity is ultimately dependent not just on how it is used for intra-mural edification but also on how things are independently of the Christian worshipper. ${ }^{43}$ Therefore, unless we assume that the gospel is meant, in a purely intra-textual manner, only for those already within the Christian faith, the scriptural text must link up with the reader who brings a specific world of meaning to it. ${ }^{44}$

\section{DEBATING CHRISTIAN PARTICULARISM}

In sum, we have arrived at three major conclusions in the preceding sections. First, the debate between Christian theologians over SP and WP is ultimately one over the possibility of 'translations' of the Christian message into vocabulary that can be shared across religious boundaries. While post-liberal theologians usually are hesitant to engage in such projects, the conceptual pressures of the doctrine that salvation is not restricted for a specific section of humanity push them in the direction of WP. Indeed, as Joseph DiNoia puts it, the universality of the divine salvific will 'has a global or overall regulative force for the construal of central Christian doctrines and, by implication, of doctrines about other religions and their 
adherents'. ${ }^{45}$ However, and this is the crucial point, the affirmation of the objective - as opposed to the merely intra-textually subjective - reality of the Christ-event as reaching out in some way through all time and space implies that Christians who seek to carry the gospel to non-Christians have to engage in some form of communication such as interreligious dialogue. Paul J. Griffiths puts this point even more strongly when he affirms that Christians who hold that the salvation of non-Christians is important are under an 'ethical imperative' to engage in positive apologetics. ${ }^{46}$ That is, the question, 'Why Jesus Christ?', becomes a live one especially in the context of interreligious dialogue when Christians may be called upon to provide reasons for their faith centred in Christ.

Second, the debate over SP and WP is, therefore, integrally connected to another raging dispute among Christian theologians over the possibility of 'natural theology', that is, whether one can develop a comprehensive account of the Christian hope in terms that would be accessible to non-Christians. Post-liberal theologians sometimes argue that human reasoning that tries to proceed independently of God's self-disclosure in Christ cannot arrive at the full content of the Christian revelation, and no cognitive defence can be provided of the Christian scheme through which Christians organize reality. They are opposed by theologians who seek to integrate the Christian vision, revolving around Jesus Christ as the criterion, with the common world that Christians share with those outside the horizon of their faith. ${ }^{47}$ F.C. Coppleston, for instance, argues that while Christianity did not arrive as a philosophical system and while its heart is a personal relationship to God, 'it by no means follows that any attempt to work out a synthesis in the light of Christian faith is to embark on a project contrary to the spirit of the Christian religion'. ${ }^{48}$ Theologians such as Coppleston would therefore argue that while it may be true that Christians do not typically arrive at their faith 
after a meticulous analysis of arguments offered in its support, and their faith is nurtured and sustained within communities that worship the Triune God, patterns of reasoning which seek to show that the Christian understanding of Jesus Christ is the best explanation for our world can highlight its plausibility and coherence not only to Christian themselves but also to agnostics, atheists and inquirers from other religious backgrounds.

Third, the dividing lines between SP and WP are not always sharply-drawn, for, as we noted in the case of Werpehowski, it is possible for theologians who are at the SP end of the spectrum to articulate 'reasons' in defence of Christian faith. Proponents of SP could maintain that they reject a priori 'thick descriptions' of the conversational partner, while they accept certain 'thin descriptions' drawn from their home Christian traditions, and that the latter, with due attention to context, can sometimes be translated across religious boundaries. The difference between these two possibilities is highlighted in a somewhat different context by Richard Rorty who argues that we should 'distinguish between the following two theses: (1) there is no single commensurating language, known in advance, which will provide an idiom into which to translate any new theory, poetic idiom, or native culture; and (2) there are unlearnable languages'. ${ }^{49}$ While SP seems to affirm (2), certain standpoints on interreligious dialogue which less ambiguously assert WP would claim that it is possible to read the texts of one's own traditions alongside those of others, thereby leading to extensions, interrogations, transmutations, variations, and even losses, of the established meanings of the former. ${ }^{50}$ These perspectives have sometimes employed the insights of hermeneutical perspectivism developed by figures such as Gadamer and Ricoeur to steer a via media between the thesis of radical untranslatibility and the demand of a prior common ground to facilitate conversations across boundaries. Ricoeur talks of a hermeneutic arc composed of three phases: first, we 
approach a text with our own presuppositions, interests, backgrounds, commitments and prejudices, which constitute our naïve understanding; second, critical analysis in which we seek distantiation from our 'anticipations of meaning' through methods such as historical analysis, literary criticism and so on, and allow ourselves to be confronted by the 'objectivity' of the text; and third, the 'second naivete' in which we imaginatively appropriate the alterity of the text as a resource for ourselves in the present. ${ }^{51}$ Ricoeur's claim that we can, in this manner, exercise linguistic hospitality towards alien horizons of thought is echoed, as we have seen, in Clooney's 'comparative theology', which sees religious identity not in static but in relational terms and seeks to develop modes of dialogical inter-being across boundaries. On the one hand, Clooney affirms that such inter-textual study across religious boundaries is guided not by 'pure reason' but by reason that has been 'deeply influenced by prior religious dispositions' ${ }^{52}$ Therefore, he agrees with Hindu theistic theologians against their Buddhist opponents partly because the former more closely resemble his own Christian theological standpoint. On the other hand, however, this is not an a priori projection of Christian predilections onto the Hindu other: Clooney highlights how Hindu views on the nature of the ultimate reality, divine embodiment, and so on are articulated from distinctive Hindu standpoints with their specific doctrinal structures. For instance, he notes that while the Hindu understanding of the avatara resonates with the Christian confession of the enfleshed God, Hindu theologians such as Ramanuja would, for reasons that are internal to their Vedantic worldview, deny that the divine embodiment is capable of undergoing any worldly suffering. 


\section{CONCLUSION}

Our historical excursus into the debate between Farquhar and his critics such as Hogg shows, pace post-liberal theologians, that the concern to develop the standpoints of the Christian faith and interreligious dialogue are not mutually opposed enterprises. Further, this historical exchange helps us to see that interreligious dialogue is rooted in certain theological 'presuppositions' about how the religious other is to be approached, understood and engaged. Kristin Kiblinger argues that not all forms of 'theology of religions', that is, attempts to develop a Christian framework to apprehend religious diversity, are guilty of committing the transgressions that comparative theologians sometimes attribute to them. In fact, we cannot shift to the task of reading the religious texts of other traditions without some presuppositions about the other, because these presuppositions guide us in how we perform these readings. For instance, if we read the Gitā with the view that we can encounter God in it, this presupposition already points to a certain theology of religions. ${ }^{53}$ Kiblinger's view that the two enterprises are not antagonistic is endorsed by Clooney himself who speaks of a division of theological labour between the practitioners of the two. Given that many scholars are engaged in the theology of religions, Clooney speaks of the need for scholars who undertake detailed, textual study of religions, and argues that 'in the long run, we should be able to agree that theology of religions and comparative theology mirror and imply one another, and even help one another'. ${ }^{54}$ This is a position, as we have noted, that would have been applauded by Hogg as well. 
At the same time, it is important to emphasise that comparative theology has taken firm strides since the days of Otto, Hogg and others, especially with respect to where the 'surd differences' between Christianity and Hinduism are precisely to be located. For instance, Otto's claims regarding the radical alterity of Hindu bhakti are sometimes overdetermined by his Lutheran notions of sola gratia, divine wrath, and so on, which shape his understanding of bhakti as, in effect, a Pelagian striving on the part of the Hindu devotee. Thus, he argues that in the 'Indian religion of grace', the world remains devoid of any ultimate value, the devotees do not experience a sense of personal unworthiness before the personal Lord and so on - these are 'differences' which contemporary scholars of south Indian bhakti, such as Clooney himself, have tried to deconstruct. Lindbeck therefore rightly notes that 'bilingualism' is a rare achievement, which highlights the difficulties of extra-mural communication across religious boundaries. ${ }^{55}$ However, while Lindbeck sees such difficulties as insuperable, comparative theologians who do not accept his thesis of untranslatibility across self-contained religious frameworks instead speak of situational, dialectical, hermeneutical encounters in which religious spaces are metaphorically re-visualised. ${ }^{56}$ Indeed, after speaking of the 'axial' difference between Christian 'grace' and Hindu bhakti, Otto himself goes on to emphasise that one must not ignore the presence of the governing idea of one religious system as the auxiliary elements in the other. For example, he argues that the consciousness of 'sin' is not, after all, entirely absent in the bhakti religions; whereas Ramanuja's notion of atma-siddhi, the realization of the finite self in communion with the Lord, is not totally unknown either to some of the Christian traditions and in fact resonates with the Christian motifs of the 'fulness of life', 'blessedness', and 'real being', ${ }^{57}$ Here Otto emphasises the theme of WP that is common to contemporary comparative theologians, that conversations with other religions can often foster conversations within the home religious 
traditions, setting up critical correlations where the accent can fall sometimes on similarity, and sometimes on difference.

${ }^{1}$ Partha Mitter Much maligned monsters : history of European reactions to Indian art (Oxford :
Clarendon Press, 1977)
2 Quoted in M. A. Laird Missionaries and Education in Bengal 1793-1837 (Oxford: Oxford University Press, 1972), p. 207

3 T.E. Slater The philosophy of missions: a present-day plea (London, 1882), 112.

4 J. N. Farquhar The College St. Matthew (Madras, 1909), 106.

${ }^{5}$ J. Hick, An Intepretation of Religion (Basingstoke: Palgrave, 2004).

${ }^{6}$ Paul Hedges, 'A Reflection on Typologies: Negotiating a Fast-Moving Discussion', in Christian Approaches to Other Faiths, eds. P. Hedges and A. Race (London: SCM Press, 2008), 17-33, p. 29.

${ }^{7}$ William Placher, Unapologetic Theology: A Christian Voice in a Pluralistic Conversation (Louisville, KY: Westminster/John Knox Press, 1989), 145.

${ }^{8}$ Stephen Duffy, 'The Stranger Within Our Gates', in The Myriad Christ: Plurality and the Quest for Unity in Contemporary Christology, eds. T. Merrigan and J. Haers (Louvain: Peeters, 2000), 3-30, p. 8.

${ }^{9}$ John Cobb, 'Dialogue Without Common Ground', in Weltoffenheit des christlichen Glaubens:Fritz Buri zu Ehren, eds. I. Abbt and A. Jager (Tübingen: Katzmann, 1987), 145-154, p. 148.

${ }^{10}$ Joseph A. DiNoia, OP "Teaching Differences", Journal of Religion, 73 (1993): 61-68, p.65.

${ }^{11}$ Catherine Cornille, 'Multiple Religious Belonging', in Understanding Interreligious Relations, D. Cheetham, D. Pratt and D. Thomas ed. (Oxford: Oxford University Press, 2013), 324-340, p. 333.

${ }^{12}$ George Lindbeck, The Nature of Doctrine: Religion and Theology in a Postliberal Age (London: SPCK, 1984).

${ }^{13}$ Lindbeck, The Nature of Doctrine, 49.

${ }^{14}$ George Lindbeck, 'The Gospel's Uniqueness: Election and Untranslatability', Modern Theology 13 (1997): 423-50, p.427.

${ }^{15}$ Lindbeck, The Nature of Doctrine, 59.

${ }^{16}$ William Werpehowski, ‘Ad hoc Apologetics', The Journal of Religion 66 (1986): 282-301.

${ }^{17}$ Richard Lints, 'The Postpositivist choice: Tracy or Lindbeck', Journal of the American Academy of Religion 61 (1983): 655-77.

${ }^{18}$ Francis X. Clooney, "Francis Xavier, and the World we (Don't Quite) Share", in Jesuit Postmodern: Scholarship, Vocation, and Identity in the 21st Century, ed. F. Clooney (Lanham, MD: Lexington Books, 2006), 57-180, p. 178. 
${ }^{19}$ Francis X. Clooney, 'Current Theology: Comparative Theology: a Review of Recent Books (19891995)', Theological Studies 56 (1995): 521-550, p. 522.

${ }^{20}$ Francis X. Clooney, Hindu God, Christian God: How Reason Helps Break Down the Barriers between Religions (New York, NY: Oxford University Press, 2001), 164.

${ }^{21}$ Clooney, Hindu God, Christian God, 7.

${ }^{22}$ Reid B. Locklin and Hugh Nicholson, 'The Return of Comparative Theology', Journal of the American Academy of Religion 78 (2010): 477-514.

${ }^{23}$ James L. Fredericks, 'Introduction' in The New Comparative Theology: Interreligious Insights from the Next Generation, ed. Francis X. Clooney (New York: T \& T Clark International, 2010), ix-xix.

${ }^{24}$ A. Bagus Laksana, 'Comparative Theology: Between Identity and Alterity' in The New Comparative Theology: Interreligious Insights from the Next Generation, ed. Francis X. Clooney (New York: T \& T Clark International, 2010), 1-20.

${ }^{25}$ Clooney, Hindu God, Christian God, 17.

${ }^{26}$ Clooney, Hindu God, Christian God, 27.

${ }^{27}$ Eric J. Sharpe, Not to destroy but to fulfill: the contribution of J. N. Farquhar to Protestant missionary thought in India before 1914 (Lund: Gleerup, 1965), 310-12.

${ }^{28}$ J.N. Farquhar, The Crown of Hinduism (London: Oxford University Press, 1913).

${ }^{29}$ Farquhar, The Crown of Hinduism, 51.

${ }^{30}$ D. Mackichan,'A Present-Day Phase of Missionary Theology', The International Review of Missions 11 (1914): 243-54, p.253.

${ }^{31}$ A.G. Hogg, 'Review of Books', The International Review of Missions 9 (1914): 171-74.

32 J.R. Bacon, 'The Bhagavad Gita Considered as an aid to the Christian Missionary', East and West 12 (1914): 169-83, p.178.

${ }^{33}$ A.G. Hogg, 'The Christian Attitude to Non-Christian Faith', in The Authority of the Faith: International Missionary Council Meeting at Tambaram, Madras: December $12^{\text {th }}$ to $29^{\text {th }}$, 1938 (London: Humphrey Milford, 1939), 102-25, p.120.

${ }^{34}$ Rudolf Otto, India's Religion of Grace and Christianity Compared / translated by F.H. Foster (London: SCM, 1930), 100.

${ }^{35}$ Otto, India's Religion of Grace and Christianity Compared, 66.

${ }^{36}$ A. G. Hogg, The Christian message to the Hindu (London: SCM, 1947), 28-29.

${ }^{37}$ A.G. Hogg. 'The Christian Attitude to Non-Christian Faith', in The Authority of the Faith: International Missionary Council Meeting at Tambaram, Madras: December $12^{\text {th }}$ to $29^{\text {th }}$, 1938 (London: Humphrey Milford, 1939), 102-25, pp.111-12.

${ }^{38} \mathrm{Hogg}$, The Christian message to the Hindu, 10.

${ }^{39}$ A. Hogg, 'The God that must needs be Christ Jesus', International Review of Misisons 22 (1917): 221-232, p. 222.

${ }^{40}$ James L. Fredericks, 'Introduction', The New Comparative Theology: Interreligious Insights from the Next Generation, ed. Francis X. Clooney (New York: T \& T Clark International, 2010), ix-xix.

41 A.G. Hogg, 'Review of Books', The International Review of Missions 9 (1914): 171-74, pp. 17273. 
${ }^{42}$ William C. Placher, 'Postliberal Theology', in The Modern Theologians: an introduction to Christian theology in the twentieth century, vol.2, David Ford ed. (Oxford: Basil Blackwell, 1989), 115-28.

${ }^{43}$ David Fergusson, 'Meaning, Truth, and Realism in Bultmann and Lindbeck', Religious Studies 26 (1990): 183-198.

${ }^{44}$ Terrence W. Tilley, 'Incommensurability, Intratextuality and Fideism', Modern Theology 5 (1989): 87-111.

${ }^{45}$ J.A. DiNoia The Diversity of Religions: A Christian Perspective (Washington, D.C.: The Catholic University of America Press, 1992), 107-8.

${ }^{46}$ Paul Griffiths, Apology for Apologetics: a study in the logic of interreligious dialogue (Maryknoll, New York: Orbis Books, 1991), 16.

${ }^{47}$ Alister E. McGrath, Open Secret: a new vision for natural theology (Oxford: Blackwell, 2008).

${ }^{48}$ F.C. Coppleston, 'Faith and Philosophy', in Religion, Reason and the Self, S.R. Sutherland and T.A. Roberts ed. (Cardiff: University of Wales Press, 1989), 47-59, p.57.

${ }^{49}$ Richard Rorty, Objectivity, Relativism, and Truth (Cambridge, Cambridge University Press, 1991), 215.

${ }^{50}$ Francis X. Clooney, 'Reading the World in Christ: From Comparison to Inclusivism', in Christian Uniqueness Reconsidered: The Myth of a Pluralistic Theology of Religions, ed. Gavin D'Costa (Maryknoll, NY: Orbis Books, 1990), 63-80, p. 70.

${ }^{51}$ P. Ricoeur, Hermeneutics and the Human Sciences: Essays on Language, Action and Interpretation (Cambridge: Cambridge University Press, 1998).

${ }^{52}$ Clooney, Hindu God, Christian God, 49.

${ }^{53}$ Kristin Beise Kiblinger, 'Relating Theology of Religions and Comparative Theology' in The New Comparative Theology: Interreligious Insights from the Next Generation, Francis X. Clooney ed.(New York: T \& T Clark International, 2010), 21-42.

${ }^{54}$ Francis X. Clooney, 'Response', in The New Comparative Theology: Interreligious Insights from the Next Generation, ed. Francis X. Clooney (New York: T \& T Clark International, 2010), 191200, p.196.

${ }^{55}$ Lindbeck, 'The Gospel's Uniqueness: Election and Untranslatability', 427.

${ }^{56}$ Hugh Nicholson, 'Comparative Theology After Liberalism', Modern Theology 23 (2007): 229-51.

${ }^{57}$ Otto India's Religion of Grace and Christianity Compared, 93-4. 